\title{
ANALISIS BIAYA, VOLUME, DAN LABA PADA USAHA PENGGILINGAN IKAN TENGGIRI DI KOTA BENGKULU (STUDI KASUS HOME INDUSTRY BINTANG LAUT)
}

\author{
COST, VOLUME, DAN PROFIT ANALYSIS OF GRINDING FISH IN \\ BENGKULU CITY (CASE STUDY HOME INDUSTRY BINTANG LAUT)
}

\author{
Nurul Chairunnisa, Reswita, dan Irnad, \\ Jurusan Sosial Ekonomi Pertanian Fakultas Pertanian Universitas Bengkulu \\ Email reswita17@yahoo.co.id
}

\begin{abstract}
Research aims to calculate income, the break event point, profitability, and sensitivity at a venture grinding fish Bintang Laut. Analysis methods used was a qualitative methodology. Value analysis of income business sector was Rp 10.312.343,17. Break event point $a$ is 18,84 kilogram or Rp 1.876.116,65. And value for profitability is $17 \%$ and value for sensitivity is $R p 1,03$. Based on the research, can be concluded that this business advantageous and can increase profit by means of increase production and boost sales
\end{abstract}

Keyword: grinding fish, income, break-even point, profitability and sensitivity

\section{PENDAHULUAN}

Ikan merupakan sumber protein yang bernilai tinggi dibandingkan dengan sumber protein hewani lainnya. Kandungan gizi yang terdapat pada ikan yaitu protein sebesar 16-24\%. Selain itu, ikan juga mengandung lemak antara 0,2-22\% (Susanto, 2005). Salah satu ikan yang memiliki kandungan gizi yang tinggi yaitu ikan tenggiri (Scomberomorus commerson). Protein yang terkandung dalam ikan tenggiri yaitu sebesar 18,50\%, lemak 2,70\%, karbohidrat sebesar 5,13\%, abu 1,40\% dan air sebanyak 77,40\%. Sebagian besar wilayah Provinsi Bengkulu merupakan wilayah perairan. Berbagai jenis ikan dari peraian Provinsi Bengkulu, salah satunya yaitu ikan tenggiri. Volume produksi ikan tengiri yang cukup besar, sehingga banyak masyarakat Kota Bengkulu membangun usaha dari bahan baku ikan tenggiri, salah satunya adalah usaha daging giling ikan tenggiri.

Ikan tenggiri mempunyai banyak kelebihan. Selain memiliki kandungan gizi yang tinggi, ikan tenggiri juga dapat diolah menjadi makanan olahan. Banyaknya permintaan terhadap ikan tenggiri ini juga mendorong tumbuhnya usaha penggilingan ikan tenggiri. Ikan tenggiri giling merupakan olahan dari ikan tenggiri segar yang dihancurkan atau digiling menjadi bahan baku makanan. 
Beberapa penggilingan ikan tenggiri di Kota Bengkulu yaitu Bintang Laut, Annisa 88, Rara, Berlin, Nindy, 3 Putri, Anton dan AL3. Dari beberapa usaha penggilingan di atas, ada yang telah mendapatkan izin dari Departemen Kesehatan, yaitu Bintang Laut. Bintang laut ini adalah satu-satunya usaha penggilingan ikan tenggiri yang sudah melalui uji tes dari Departemen Kesehatan dan telah mendapatkan Nomor Industri Rumah Tangga (IRT). Selain itu untuk pemasaran, hanya produksi ikan tenggiri giling dari Bintang Laut yang sudah memasuki salah satu mini market di Kota Bengkulu.

Ada tiga produk yang dihasilkan dari Bintang Laut, yaitu daging ikan tenggiri super, daging merah, dan kulit. Semua produk tersebut berasal dari bahan baku yang sama, yakni ikan tenggiri segar. Tetapi untuk produksinya, ada atau tidaknya ikan tenggiri yang tersedia tergantung dengan cuaca. Jika cuaca sedang buruk maka produksi akan menurun, sehingga harga ikan tenggiri pun akan mengalami kenaikan. Maka dari itu, untuk mencapai laba yang diharapkan yang merupakan ukuran keberhasilan usaha harus dilakukan analisis biaya, volume, dan laba untuk dapat menambah ketepatan dalam membuat perencanaan produksi dan penjualan (Jumingan, 2008). Selanjutnya menurut Reswita (2006), pendekatan yang dapat digunakan adalah perhitungan harga pokok produksi dan harga pokok penjualan yang tepat untuk semua produk yang dihasilkannya, perlu adanya perhitungan titik impas, kemampuan memperoleh laba serta sensitivitas. Hal ini berguna untuk mengetahui sehat atau tidaknya usaha tersebut.

Berdasarkan uraian latar belakang yang dikemukakan di atas maka penelitian ini bertujuan untuk 1) menganalisis pendapatan usaha pengolahan ikan tenggiri Bintang Laut, 2) menganalisis titik impas dan kemampuan dalam memperoleh laba usaha pengolahan ikan tenggiri Bintang Laut, 3) tingkat sensitivitas usaha penggilingan ikan Tenggiri Bintang Laut.

\section{METODE PENELITIAN}

Penelitian ini dilakukan pada usaha penggilingan ikan tenggiri Bintang Laut yang beralamat di Jl. Araw Kelurahan Berkas Kota Bengkulu. Penentuan tempat penelitian dilakukan secara sengaja (purposive). Penentuan lokasi penelitian dengan pertimbangan bahwa usaha penggilingan ikan tenggiri ini adalah satu-satunya usaha penggilingan ikan yang sudah melalui uji tes dari Departemen Kesehatan dan telah mendapatkan Nomor Industri Rumah Tangga di Kota Bengkulu. Selain itu, pemasaran yang dilakukan juga sudah sampai ke luar Kota Bengkulu. Responden dalam penelitian ini merupakan pemilik usaha penggilingan ikan tenggiri Bintang Laut di Kelurahan Berkas Kecamatan Teluk Segara Kota Bengkulu. Data yang digunakan dalam penelitian ini adalah data primer dan data sekunder.

34 | Nurul Charunisa, Reswita, dan Irnad, Analisis Biaya, Volume, Dan Laba.... 


\section{Metode Analisis Data}

\section{Perhitungan Harga Pokok Produksi}

Manfaat dari perhitungan harga pokok produksi adalah untuk menetukan harga jual produk, akurasi biaya produksi, menghitung pendapatan (rugi/laba), serta menentukan harga pokok persediaan produk jadi dan produk dalam proses (Mulyadi, 2007). Analisis yang digunakan adalah dengan metode variable costing, sebagai berikut

\section{Laporan Harga Pokok Produksi}

Pemakaian Bahan Baku

Persediaan Awal Bahan Baku

Pembelian Bahan Baku

Ongkos Angkut Pembelian

Bahan Baku Tersedia

$\operatorname{Rp} x x x$

Persediaan Akhir

Pemakaian Bahan Baku Langsung

Upah Tenaga Kerja Langsung Rp $x x x$

$\underline{\operatorname{Rp} x x x \quad+}$

Biaya Overhead Variabel

a. Biaya Penggunaan Listrik

b. Biaya Pengemasan

Rp xxx

$\operatorname{Rp} x x x+$

Harga Pokok Produksi

Sumber: Halim (2005)

\section{Perhitungan Rugi Laba}

Penyajian laporan rugi-laba menggunakan format margin kontribusi, yaitu menyajikan informasi dengan mengurangi terlebih dahulu kas tetap. (Sugiri, 2009). 


\section{Laporan Rugi/Laba}

Penjualan

Harga Pokok Penjualan

a. Persediaan barang jadi awal

b. Harga Pokok Produksi

c. Persediaan Barang Untuk Dijual

d. Persediaan Barang Jadi Akhir

Harga Pokok Penjualan

Biaya adm dan penjualan variabel

Margin Kontribusi

Biaya Tetap:

a. Biaya Overhead Pabrik

b. Biaya Admisnistrasi dan Penjualan

Laba Bersih Sebelum Pajak

a. Biaya Pajak

Laba Bersih

Sumber: Halim (2005)
$\operatorname{Rp} x x x$
$\operatorname{Rp} x x x$

$\operatorname{Rp} x x x$

$\operatorname{Rpxxx}$

$\operatorname{Rp} x x x$

$\frac{\operatorname{Rp} x x x-}{\operatorname{Rp} x x x}$

$\operatorname{Rp} x x x+$

\section{Analisis Titik Impas}

Impas adalah kondisi usaha pada saat perusahaan tidak memperoleh laba, tetapi tidak menderita rugi atau pada saat jumlah penghasilan perusahaan sama besarnya dengan jumlah biaya perusahaan. Dengan adanya titik impas, maka perusahaan mengetahui jumlah penjualan minimum (dalam unit produk maupun uang) agar perusahaan tidak menderita rugi (Halim, 2005). Menurut Garrison dan Noreen (2000) metode ini pada dasarnya adalah metode singkat dari metode persamaan, yaitu :

TitikImpas(unit) $=\frac{\text { BiayaTetap }}{\text { MArginKontribusiper unit }}$

TitikImpasPenjualan $(\mathrm{Rp})=\frac{\text { BiayaTetap }}{\text { RasioMarginKontribusi }}$

MarginKontribusi $(\mathrm{Rp})=$ Penjualan- Biaya Variabel

Rasio MarginKontribusi $=\frac{\text { MarginKontribusiTotal }}{\text { TotalPenjualan }}$

36 | Nurul Charunisa, Reswita, dan Irnad, Analisis Biaya, Volume, Dan Laba.... 


\section{Kemampuan Memperoleh Laba}

$$
\pi(\%)=\operatorname{MOS}(\%) \times \operatorname{MIR}(\%)
$$

dimana $\pi$ adalahKemampuan Memperoleh Laba (\%), MOS merupakan Margin of Safety (\%), dan MIR adalah Marginal Income Ratio (\%). MOS dan MIR diestimasi dengan rumus sebagai berikut:

$$
\begin{aligned}
& \operatorname{MOS}(\%)=\frac{\text { NilaiPenjualanAktual - NilaiPenjualanImpas }}{\text { NilaiPenjualanAktual }} \times 100 \% \\
& \operatorname{MIR}(\%)=\frac{\text { NilaiPenjualan - Biaya Variabel }}{\text { NilaiPenjualan }} \times 100 \%
\end{aligned}
$$

\section{Analisis Sensitivitas}

Untuk mengukur pengaruh perubahan volume penjualan terhadap profitabilitas (laba) atau untuk mengetahui kepekaan laba terhadap perubahan volume penjualan.

$$
\text { DOL }=\frac{\text { MarginKontribusi }}{\text { LabaBersih }}
$$

\section{HASIL DAN PEMBAHASAN}

\section{Harga Pokok Produksi Daging Giling Beku}

Harga pokok produksi pada usaha penggilingan ikan tenggiri Bintang Laut adalah sebesar Rp 70.875,55. Harga pokok produksi diperoleh dari keseluruhan biaya produksi variabel yang dikeluarkan dibagi dengan total produksi yang dihasilkan (lihat Tabel 1).

Tabel 1 Harga Pokok Produksi dengan metode Variable Coasting Pada Usaha Penggilingan Ikan Tenggiri Bintang Laut

\begin{tabular}{llr}
\hline No & \multicolumn{1}{c}{ Uraian } & \multicolumn{1}{c}{ Total (Rp) } \\
\hline 1 & Pembelian Bahan Baku & $44.606 .500,00$ \\
2 & Upah Tenaga Kerja & $6.660 .000,00$ \\
3 & Biaya Overhead Pabrik Variabel & \\
4 & $\quad$ Biaya Listrik & $538.217,00$ \\
5 & Biaya Pengemasan & $369.000,00$ \\
6 & Biaya Penyimpanan & $360.000,00$ \\
7 & Total Biaya Overhead Pabrik (4+5+6) & $1.267 .217,00$ \\
8 & HPP (1+2+7) & $52.533 .717,00$ \\
9 & HPP Per unit (9/jumlah produksi) & $\mathbf{8 3 . 6 5 2 , 0 0}$ \\
\hline
\end{tabular}

Sumber: Diolah dari data primer 
Bahan baku dalam penggilingan ikan tenggiri adalah ikan tenggiri segar. Ikan tenggiri segar yang didapatkan penggilingan ikan Bintang Laut, ada yang berasal dari nelayan sekitar, dari kapal langsung, ataupun dari luar kota. Biaya bahan baku yang dikeluarkan pada bulan penelitian adalah sebanyak Rp 44.606.500,00. Jumlah pembelian ikan segar yaitu sebanyak 999,2 kg dengan harga rata-rata Rp. 44,642,21. Tenaga kerja yang bekerja di penggilingan ikan tenggiri Bintang Laut adalah tenaga kerja luar keluarga. Jumlah tenaga yang dimiliki yaitu 5 orang. Jumlah biaya yang dikeluarkan untuk tenaga kerja selama 1 bulan pada bulan penelitian yaitu sebesar Rp 6.660.000. Biaya overhead pabrik tetapterdiri dari biaya beban penggunaan listrik, penyusutan alat, penyusutan gedung serta biaya administrasi dan penjualan tetap. Yang termasuk dalam biaya overhead variabel adalah penggunaan listrik, pengemasan dan juga penyimpanan (es balok). Jumlah BOP tetap yang dikeluarkan selama 1 bulan berjumlah Rp. 183.460 dan jumlah BOP variabel sebanyak Rp. 1.267.217. Jumlah produksi yang dihasilkan usaha penggilingan ikan tenggiri Bintang Laut selama 1 bulan penelitian adalah sebanyak $628 \mathrm{~kg}$.

\section{Perhitungan Rugi Laba}

Hasil perhitungan rugi laba secara rinci disajikan pada Tabel 2.

Tabel 2 Laporan rugi/laba Usaha Penggilingan Ikan Tenggiri Bintang Laut.

\begin{tabular}{clr}
\hline No & \multicolumn{1}{c}{ Uraian } & Total (Rp) \\
\hline 1 & Pendapatan & $59.660 .000,00$ \\
& Penjualan Produk Utama & $3.620 .000,00$ \\
& Penjualan Produk Sampingan & $63.280 .000,00$ \\
\hline & Total Penjualan & $52.533 .717,00$ \\
\hline 2 & Biaya Variabel & $115.000,00$ \\
& HPP - Biaya Produksi & $52.648 .717,00$ \\
& Biaya adm dan umum variabel & $10.631 .283,00$ \\
& $\quad$ Total & $181.574,00$ \\
\hline 3 & Margin Kontribusi (1-2) & $1.886,00$ \\
\hline 4 & Biaya Tetap & $106.312,83$ \\
& BOP Tetap & $29.167,00$ \\
& Biaya adm dan umum tetap & $135.479,83$ \\
& Pajak & $318.939,83$ \\
& Pph 1\% dari laba kotor & $10.312 .343,17$ \\
& PBB
\end{tabular}

Sumber: Diolah dari data primer

38 | Nurul Charunisa, Reswita, dan Irnad, Analisis Biaya, Volume, Dan Laba.... 
Laporan rugi laba disusun untuk mengetahui apakah usaha pengolahan ikan tenggiri memperoleh laba atau mengalami kerugian. Daging giling ikan tenggiri yang dihasilkan dijual dengan harga Rp. 95.000 per kg. Selisih harga jual daging ikan tenggiri giling dengan harga pokok produksi per kg sebesar Rp. 11.348. Laba bersih yang diperoleh usaha pengolahan ikan tenggiri selama 1 bulan sebesar Rp. 10.312.343,17. Hasil ini mengindikasikan bahwa usaha pengilingan ikan tenggiri ini menguntungkan dan layak dikembangkan.

\section{Analisis Break Event Point, Kemampuan Laba, dan Sensitivitas}

Analisis Break Event Point point memang sangat diperlukan dalam suatu usaha. Tujuannya, agar dapat mempertahankan usahanya dengan mengetahui volume minimal dalam produksinya. Berikut perhitungan break event point pada usaha penggilingan ikan tenggiri Bintang Laut.

Tabel 3 Analisis Break Event Point (Titik Impas) pada usaha penggilingan ikan tenggiri Bintang Laut

\begin{tabular}{clr}
\hline No & \multicolumn{1}{c}{ Uraian } & \multicolumn{1}{c}{ Total } \\
\hline 1 & Penjualan (Rp) & $63.280 .000,00$ \\
2 & Biaya Variabel (Rp) & $52.648 .717,00$ \\
3 & Margin kontribusi (1-2) (Rp) & $10.631 .283,00$ \\
4 & Biaya Tetap (FC+Pajak) (Rp) & $318.939,83$ \\
5 & Laba (3-4) (Rp) & $10.312 .343,17$ \\
6 & MC per unit (3/Total Penjualan) (Rp) & $16.928,79$ \\
7 & Rasio MC (3/1) & 0,17 \\
8 & BEP per Unit (4/6) (Rp/ unit) & 18,84 \\
9 & BEP per Rupiah (4/7) & $1.876 .116,65$ \\
10 & MOS (\%) & 97,04 \\
11 & MIR (\%) & 17,00 \\
12 & Kemapuan memperoleh laba(\%) & 16,50 \\
13 & DOL & 1,03 \\
\hline
\end{tabular}

Sumber: Diolah dari data primer

Titik impas usaha penggilingan ikan tenggiri Bintang Laut terjadi saat penjualan sebanyak 18,84 kilogram dengan hasil penjualan yaitu sebesar Rp. $1.876 .116,65$, yang berarti pada kondisi ini usaha tidak menderita kerugian tetapi juga belum mendapatkan keuntungan. Apabila perusahaan ingin memperoleh keuntungan maka harus menjual produk diatas titik impas. Nilai MOS adalah sebesar $97,45 \%$, sedangkan nilai MIR adalah 18,01\%. Perkalian besar nilai dari MOS dan MIR tersebut adalah 16,5\%. Hasil tersebut menunjukkan bahwa kemampuan usaha pengilingan ikan tenggiri Bintang Laut untuk menghasilkan laba sebesar $16,5 \%$. DOL menggambarkan berapa kali perubahan laba akibat perubahan penjualan atau sensitivitas usaha. Nilai sensitivitas sebesar 1,02. Ini 
menunjukkan bahwa setiap kenaikan $1 \%$ penjualan maka laba usaha pengolahan ikan tenggiri Bintang Laut akan meningkat sebesar 1,02\%.

\section{SIMPULAN DAN SARAN}

\section{Simpulan}

1. Pendapatan yang diperoleh pada usaha penggilingan ikan tenggiri Bintang Laut Kota Bengkulu yaitu sebesar Rp 10.312.343,17

2. Titik impas "Bintang Laut" adalah Rp 1.876.116,65 atau sebesar 18,84 kilogram daging giling beku dan kemampuan memperoleh laba sebesar $16,5 \%$.

3. Bintang Laut memiliki nilai Operating Leverage sebesar 1,02, artinya jika penjualan meningkat $1 \%$, maka laba akan meningkat sebesar $1,03 \%$.

\section{Saran}

Pentingnya penggilingan ikan tenggiri Bintang Laut Kota Bengkulu untuk meningkatkan produksi dan juga penjualan. Peningkatan produksi bisa dilakukan dengan jumlah banyak pada musim ikan dan melakukan penyimpanan yang dapat dijual pasa saat tidak musim ikan. Hal ini umtuk menjaga kontinuitas pasokan.

\section{DAFTAR PUSTAKA}

Garrrison RH dan Norren EW, 2000. Akuntansi Manajerial, buku Satu,Terjemahan A.Totok Budi Santoso. Jakarta (ID): Salemba Empat.

Halim. 2005. Akuntansi Manajemen, Cetakan Kesebelas. BPFE. Yogyakarta. Jumingan. 2008. Analisis Laporan Keuangan. PT. Bumi Aksara. Jakarta Mulyadi, 2007. Akuntansi Biaya. BPFE-UGM, Yogyakarta.

Reswita, 2006. Penuntun Praktikum Akuntansi Manajemen. Jurusan Sosial Ekonomi Pertanian. Fakultas Pertanian. Universitas Bengkulu.

Sugiri, 2009. Akuntasi Manajemen, Edisi keempat. UPP STIM YKPN, Yogyakarta. Susanto. 2005. Budidaya Ikan di Pekarangan edisi revisi. Penebar Swadaya. Jakarta.

40 | Nurul Charunisa, Reswita, dan Irnad, Analisis Biaya, Volume, Dan Laba.... 